\title{
IGUALDADE E DIFERENÇA: DIÁLOGOS SOBRE O CAMPONÊS, A MULHER E A CRIANÇA NO ROMANCE NOVENTA E TRÊS DE VICTOR HUGO
}

DOI: http://dx.doi.org/10.1590/2236-3459/59434

\author{
Alceu Ravanello Ferraro \\ Universidade Federal do Rio Grande do Sul, Brasil.
}

\section{$\cos 80$}

\begin{abstract}
Resumo
Este trabalho aborda a relação entre igualdade e diferença no romance Noventa e três de Victor Hugo, que trata da Guerra da Vendeia (1793), isto é, a contrarrevolução pelo restabelecimento da monarquia na França. Nesse romance histórico o autor discute, particularmente, duas concepções em conflito entre os revolucionários franceses, representadas pela espada e pelo machado, sobre o tipo de república a implantar e a possibilidade de igualdade do camponês, da mulher e da criança em relação, respectivamente, ao citadino, ao homem e ao adulto. Quanto ao destino da criança ganham relevo, no romance, as duas utopias revolucionárias em disputa: a caserna obrigatória e a escola obrigatória.

Palavras-chave: igualdade e diferença, camponês, mulher, criança, escola.
\end{abstract}

\section{EQUALITY AND DIFFERENCE: DIALOGUES ABOUT THE PEASANT, THE WOMAN AND THE CHILD IN THE NINETY-THREE VICTOR HUGO'S NOVEL}

\begin{abstract}
This article discusses the relationship between equality and difference in the Ninety-three Victor Hugo's novel, which deals with the War in the Vendée (1793), i.e. the counter-revolution for the restoration of the monarchy in France. In this historical novel the author discusses two conflicting views among the French revolutionaries, represented by the sword and the axe, about the kind of Republic to be implanted and the possibility of equality of the peasant, the woman and the child in relation to the city dweller, the man and the adult. As far as the fate of the child is concerned, the novel highlights two revolutionary utopias in dispute, viz. compulsory military service and compulsory school education.

Key-words: equality and difference, peasant, woman, child, school.
\end{abstract}




\section{IGUALDAD Y DIFERENCIA: DIÁLOGOS SOBRE EL CAMPESINO, LA MUJER Y EL NIÑO EN LA NOVELA NOVENTA Y TRES DE VÍCTOR HUGO}

\section{Resumen}

Este trabajo trata de la relación entre igualdad y diferencia en la novela Noventa y tres de Víctor Hugo, versando sobre la guerra de la Vendée (1793) - la contrarrevolución por la restauración de la monarquía en Francia. En esta novela histórica, el autor discute, en particular, dos concepciones en conflicto entre los propios revolucionarios, representadas por la espada y por el hacha, respecto al tipo de república a implantar y respecto a la posibilidad de igualdad del campesino, de la mujer y del niño en relación, respectivamente, con el ciudadano, con el hombre y con el adulto. En lo que atañe al destino del niño, ganan protagonismo en la novela las dos utopías revolucionarias en disputa: el cuartel obligatorio y la escuela obligatoria.

Palabras-clave: igualdad y diferencia, campesino, mujer, niño, escuela.

\section{ÉGALITÉ ET DIFFERENCE: DIALOGUES SUR LE PAYSAN, LA FEMME E L'INFANT DANS LE ROMAN QUATREVINGT-TREIZE DE VÍCTOR HUGO}

\section{Résumé}

Cet article traite de la relation entre égalité e difference dans le roman Quatrevingt-treize de Victor Hugo sur la guerre de la Vendée (1793), c'est à dire la contre-révolution pour la restauration de la monarchie en France. Dans ce roman historique l'auteur discute particulièremente deux conceptions en conflict entre les revolutionaires français, reprérentées par l'épée e le hache, sur le type de république à implanter e la possibilité d'égalité du paysan, de la femme e de l'enfant par rapport au citoyen, à l'homme e à l'adult. En ce que se rapporte à la destinée de l'enfant, gagnent proéminence les deux utopies révolutionaires en confrontation: la caserne obligatoire e l'école obligatoire.

Mots-clé: égalité et diffference, paysan, femme, enfant, école. 


\section{A questão}

ste trabalho aborda a questão da relação entre igualdade e diferença em Quatrevingt-treize (Noventa e três ${ }^{1}$ [1793]), último romance de Victor Hugo ${ }^{2}$, publicado em 1874, pouco depois de seu regresso do exílio (1870) e da Comuna de Paris (1871). Mesmo não tratando diretamente de educação, a atenção voltase, aqui, para a maneira como Victor Hugo abordou o tema da igualdade e da diferença com respeito às relações campo-cidade, de gênero e de geração, que são de fundamental importância no estudo da educação. Tudo isto em articulação com a disputa entre as duas correntes revolucionárias francesas, simbolizadas pela espada e o machado, sobre a concepção de república.

Há que salientar também que se trata do Victor Hugo de 1874, naquele que foi o seu último romance. Na realidade trata-se do autor do romance que, em certo sentido, foi "o último suspiro do romance histórico romântico", como observa Lukács (2011, p. 313). Um romance histórico que foi recebido com relativa frieza na própria França e que ainda hoje é "pouco estudado nos meios acadêmicos e pouco conhecido pelos leitores em geral" e cuja escassa difusão no Brasil é atribuída ao fato de que as obras tardias do Romantismo "já não apresentavam grandes novidades nas rodas literárias" no final do século XIX (Ribeiro, 2008, p. 145). Talvez também pelas posições político-ideológicas do autor, principalmente a partir de sua ruptura com Luís Bonaparte após o golpe de Estado de 1851.

Com uma vida que marcou presença em quase todo o século 19 (1802-1885), a atividade artística e literária de Victor Hugo estendeu-se por sete décadas, com início em 1816, ainda sob o império de Napoleão Bonaparte, indo da poesia ao teatro, ao romance, ao desenho, à fotografia. Ele teve também uma participação intensa na vida política: como confidente do rei Luís Felipe (1844), como par de França ${ }^{3}$ (1845), como integrante eleito da Assembléia Legislativa (1849); como defensor da Polônia, repartida entre diferentes nações, contra a pena de morte (Hugo, 2000b), contra o levante operário de junho de 1848 , na condição de prefeito da $8^{a}$. Circunscrição de Paris, mas também contra a política reacionária do golpista Luís Bonaparte ${ }^{4}$, que ele ajudara a eleger, novamente como deputado (1871) e finalmente como senador (1876 e 1882).

\footnotetext{
${ }^{1}$ Quando procedia à revisão final do texto, tive oportunidade de tomar conhecimento de O romance histórico de György Lukács, publicado pela Boitempo, no qual, nas referências a Victor Hugo, o título Quatrevingttreize é traduzido simplesmente por 1793. Mesmo assim, ao referir o título em português, optei pela tradução literal Noventa e três em vez de 1793.

2 Impõe-se um registro que quer também traduzir o meu profundo reconhecimento. Se, a partir de meados da década de 1990, passei a dar atenção à literatura clássica, com desdobramentos inclusive em textos meus sobre educação, devo isto a Marlene Ribeiro, minha esposa, leitora assídua desde criança e, depois que nos conhecemos, uma presença sempre desafiadora.

${ }^{3}$ Legitimista no período da Restauração que se seguiu à queda de Napoleão, com a Revolução de 1830 e a instalação do reinado constitucionalista do duque de Orleans, Luís Felipe, em aliança com a burguesia financeira, Victor Hugo passou a assumir posições liberais e a manter relação até de certa intimidade com o rei - confidente. Por fim, já quase ao final do reinado de Luís Felipe, em 13 de abril de 1845, foi nomeado pair de France (par [do reino] da França). Par tem o sentido de igual em dignidade. Trata-se de uma distinção, não propriamente de um título de nobreza, embora havendo com frequência sobreposição, como no caso dos pares-duques. Tal distinção era concedida a um tipo especial de vassalos - os grandes senhores feudais.

${ }^{4} \mathrm{O}$ livro de Victor Hugo Napoléon, le petit é resultado dessa ruptura.
} Hist. Educ. [Online] Porto Alegre v. 20 n. 48 Jan./abr., 2016 p. $281-302$ 
Filho de um general, por influência da mãe, manteve-se por longo tempo partidário do regime monárquico e aliado dos legitimistas. Após o golpe de dezembro de 1851 exilou-se na Bélgica e, depois, na ilha de Jersey, só retornando à França em 1870. Foi sempre contrário ao comunismo, mas, como senador em 1876, defendeu a anistia dos communards, participantes do levante conhecido como Comuna de Paris (1871). Foi, por vezes, identificado como socialista, embora não se professasse tal. Isto tudo para dizer que seria um equívoco pretender encontrar unidade e coerência de posição em toda a vida e obra do autor. É talvez Lukács (2011, p. 101) quem melhor distingue esses dois períodos da vida e obra do autor: primeiro, ao dizer que o romance Noventa e três foi escrito por Victor Hugo "muito tempo depois de ter rompido com os princípios políticos do legitimismo reacionário e ter se tornado o guia literário e ideológico dos movimentos liberais de oposição", depois, ao sustentar que, nessa obra, encontraríamos "importantes tendências progressistas de reavivamento da democracia revolucionária" (Lukács, 2011, p. 314). Avaliação esta que põe Victor Hugo entre os liberais de esquerda, como o marquês de Condorcet, John Dewey e John Maynard Keynes, não raro chamados, por isso, de socialistas pela direita liberal.

A trama do romance Noventa e três desenrola-se na França no período do Terror ${ }^{5}$, focando, especificamente, na guerra travada entre os revolucionários republicanos e os contrarrevolucionários realistas que queriam o restabelecimento da monarquia. Foi uma guerra entre o campo, o interior rural da França, personificado na Bretanha monarquista, ainda feudal, contra Paris, a cidade republicana, a cidade da Revolução Francesa. É nesse contexto e no quadro das ações que tiveram lugar nessa guerra, que Victor Hugo dirigiu a atenção também para a condição e o destino dos diferentes: o camponês, a mulher e a criança, aqui tomados como personagens importantes para o presente estudo, por mais que se lhes atribuam papéis de simples coadjuvantes (Ribeiro, 2008) ou de mero pretexto para ressaltar o perfil dos personagens centrais envolvidos no conflito: o marquês de Lanténac e seu sobrinho-neto, o visconde Gauvain (Marinho, 2011), comandante da Coluna Expedicionária do Exército das Costas, que combatia Lanténac.

\section{História e lenda}

Pode parecer estranho e até inadequado que se recorra a um romance para discutir a relação entre igualdade e diferença. No entanto, acompanha-se o ponto de vista de Victor Hugo. Se, em O homem que ri, ele sustentara que a história não está mais certa do que diz do que a lenda (Hugo, 2002a), em Noventa e três o confronto entre historia e lenda assume uma forma mais lapidar:

A história tem a sua verdade, a lenda tem a sua. A verdade lendária é de natureza diferente daquela da verdade histórica. A verdade lendária é a invenção que tem como resultado a realidade. De resto, a história e a lenda têm o mesmo objetivo, pintar sob o homem do momento o homem eterno. (Hugo, 2001, p. 268) ${ }^{6}$

\footnotetext{
${ }^{5}$ Período da Revolução Francesa que vai da votação da Lei dos Suspeitos, de 5 de setembro de 1793, até a queda de Robespierre, em 27 de julho de 1794.

${ }^{6}$ É da responsabilidade do autor deste artigo a tradução de todas as citações de Quatrevingt-treize. Hist. Educ. [Online] Porto Alegre v. 20 n. 48 Jan./abr., 2016 p. 281-302
} 
E o autor justifica: "A Vendeia não pode ser completamente explicada a menos que a lenda complete a história". Mas como poderá a lenda completar a história? "Precisa-se da história para o conjunto", esclarece Hugo, "e da lenda para o detalhe" (Hugo, 2001, p. 268).

Portanto, tratando-se de uma lenda, na análise de Noventa e três há que se atentar, principalmente, para os detalhes, para aquilo que escapa ao trabalho historiográfico simplesmente por falta de fontes documentais. Até porque os detalhes, como os papéis ditos coadjuvantes, desempenhados por figuras do povo, como a vivandeira, a mulher camponesa, as suas três crianças, o mendigo, o próprio sargento do Batalhão do Boné Vermelho, como se verá, muito provavelmente não teriam merecido registros naquilo que iria constituir as fontes documentais de que se poderia valer o historiador. Por isso tudo entende-se que essa atenção dada ao detalhe, tanto no romance, quanto na análise que dele se irá fazer, poderá contribuir para a compreensão do conjunto da Guerra da Vendeia, com elementos que habitualmente escapam ao registro tanto dos fatos reais, quanto da cronologia do seu acontecer.

Essa maneira de conceber a relação entre história e lenda, que poderia ser pensada também como relação entre sociologia, ciência política e lenda, não é exclusividade do romancista Visto Hugo. Ela aparece, por exemplo, na obra Os estabelecidos e os outsiders: sociologia das relações de poder a partir de uma pequena comunidade, em que os autores expressam entendimento semelhante ao tratarem da relação entre sociologia, história e lenda. É o que se infere do posfácio à edição alemã da referida obra, intitulado Outras facetas da relação estabelecidos-outsiders: o modelo Maycomb (Elias; Scotson, 2000). No referido posfácio os autores dedicam nada menos do que 15 páginas à questão das semelhanças e diferenças entre o seu estudo, científico, sobre a comunidade Winston Parma e o romance Who Kill the Mockingbird?, de 1960, de Harper Lee (2007), que se desenrola na cidade de Maycomb, no Estado sulista do Alabama, nos Estados Unidos: "Tanto em Winston Parma - dizem os autores - quanto em Maycomb nos deparamos com uma relação estabelecidos-outsiders típica. São semelhantes, apesar de estarem muito longe de ser iguais." Com efeito, tanto o livro científico, quanto o romance best-seller tratam, por exemplo, de estabelecidos e outsiders, de estigmatização, de estereótipos, de preconceitos e de violência (Elias; Scotson, 2000).

Outro aspecto a considerar relativamente ao romance Noventa e três, é que este foi escrito no final do terceiro quartel do século 19, século este em que, como observa Daibert Junior (2010) em texto em que trata de Os sertões de Euclides da Cunha, a historiografia e o romance teriam passado por um distanciamento. Mas um distanciamento que não chegou a ser total, o que permite ao autor citado sustentar que a obra de Euclides da Cunha, "situada nas nuances da fronteira entre História e Literatura", se constituiria em "espaço privilegiado para o estudo de nossa sociedade" (p. 76).

Como observa Ribeiro (2008, p. 131), Noventa e três se insere na literatura francesa e na obra de Victor Hugo "como um resgate dos ideais revolucionários" e, poder-se-ia acrescentar, dos ideais republicanos, que se haviam sobreposto, na vida do autor, aos ideais conservadores e monarquistas do primeiro período de sua vida.

Importa também ter presente que Victor Hugo não é um autor que faça habitualmente parte das fontes teóricas ou históricas consagradas ou, ainda, a que se tenha recorrido nos estudos sobre os temas que aqui interessam. Assim, apesar de sua 
posição clara e decidida no que concerne às relações de gênero, o autor não figura, por exemplo, entre os poucos homens contemplados mais detidamente na obra de Bénoîte Groult (2010), Le feminisme au masculin. Mas cabe uma ressalva: no prefácio a autora cita texto em que Victor Hugo diz que a mulher continuava sendo "uma menor segundo a lei" e "uma escrava segundo a realidade"; que na legislação francesa "a mulher não possui nada, ela não testemunha na justiça, ela não vota, ela não conta, ela não existe. Há cidadãos, mas não há cidadãs. Está aí um estado violento: é necessário que ele acabe" (apud Groult, 2010, p. 12).

Da mesma forma, em que pese o primor do livro primeiro da terceira parte de Os miseráveis, dedicado ao moleque de Paris, personificado no garoto Gavroche (Hugo, 2002b), bem como as figuras infantis presentes na obra aqui considerada, Hugo não costuma figurar nos estudos de história da infância e de sociologia da infância. Por fim, ressalvada a influência de Victor Hugo nos textos de Euclides da Cunha sobre a Guerra de Canudos - Diário de uma expedição e Os sertões -, no geral ele é pouco lembrado nos estudos sobre a relação campo-cidade, da mesma forma que na história da educação.

Em relação a este último aspecto, mesmo que a questão da alfabetização e escolarização na França ao tempo da Revolução Francesa seja tocada muito rapidamente em algumas passagens do romance em exame, há que reconhecer que o autor apresenta duas questões fundamentais. A primeira refere-se a quanto a eventual alfabetização do mensageiro Halmalo poderia ter atrapalhado os planos do chefe contrarrevolucionário Lanténac: "Um homem que lê pode criar embaraço". (Hugo, 2001, p. 120). A segunda está na retomada explicita, pelo autor, do princípio republicano da educação universal, tão bem posto, entre outros, por Condorcet (2010, 2008), mas ainda à espera de reconhecimento legal, o que só ocorreria com as leis Jules Ferry no início da década de 1880. É de interesse para a história da educação o fato de o autor haver explicitado o conflito de interesses quanto à educação universal, obrigatória e pública entre os próprios revolucionários franceses. O romance deixa claro que essa universalização do acesso à educação escolar pressupõe a priorização da escola sobre o serviço militar, a igualdade de direitos da mulher em relação ao homem e do camponês, inclusive dos broncos habitantes da Bretanha em relação aos citadinos. Ora, a concepção dominante no período imediatamente anterior, manárquico, ia na direção oposta: "O ódio pela educação dos filhos do povo era então um dogma. - Para que serve essa meia-luz? - Tal era a palavra de ordem." (Hugo, 2002b, II, p. 23);

Dito isto é hora de definir melhor o que se pretende neste artigo. O foco é o tema da igualdade e diferença no romance Noventa e três, tema este que Victor Hugo situa no período do Terror, no final do século 18, na França. O autor chama a atenção do leitor para algumas situações concretas: do camponês, da mulher e da criança, e para três relações sociais específicas: citadino-camponês, homem-mulher, adulto-criança. Situações e relações estas, estreitamente entrelaçadas.

Entende-se que não há nada de anacrônico nas discussões sobre igualdade e diferença situadas por Victor Hugo no ano de 1793. O curto período de 1790 a 1794 ganha relevo pela presença de figuras como a feminista inglesa Mary Wollstonecraft, a feminista francesa Olympe de Gouges e o também feminista francês marquês de Condorcet, que se distinguiram na luta pelos direitos humanos, especialmente em relação à mulher e à educação universal. 
É por tudo isto que o romance Noventa e três de Victor Hugo se revela importante não só para o entendimento da guerra de extermínio entre cidade e campo, entre república e monarquia, que teve lugar na França na última década do século 18, mas também para a compreensão da não menos trágica luta entre diferentes concepções de república e entre diferentes entendimentos da relação entre igualdade e diferença no que respeita às relações cidade-campo, homem-mulher e adulto-criança.

\section{O camponês bretão ou a Vendeia contra a Convenção}

$\mathrm{Na}$ introdução à edição francesa aqui utilizada, Leuilliot (2001, p. 34) esclarece a diferença entre a Vendeia, região insurgida contra a Revolução Francesa, e a Convenção, comandada pelos revolucionários Robespierre, Danton e Marat: "Na Vendeia, os chouans têm necessidade de alguém que fale em seu nome e não são designados a não ser por seus nomes de guerra", ao passo que coisa bem diferente acontece na Convenção, "cujos membros têm um nome e, em sua maior parte, uma reputação, e onde cada um padece de ataque de eloquência".

Victor Hugo esclarece quem lutava contra quem e o que estava em jogo:

Tinha chegado o ano de [17]93.

93 é a guerra da Europa contra a França e da França contra Paris. E o que é a Revolução [Francesa]? É a vitória da França sobre a Europa e de Paris sobre a França. Daí a imensidão desse minuto terrível, 93, maior que todo o resto do século.

Nada de mais trágico, a Europa atacando a França e a França atacando Paris. Drama que tem a estatura de uma epopeia. (Hugo, 2001, p. 179)

Com início na Vendeia, no Oeste da França, ao Sul rio Loire, a insurreição levou o nome de Guerra da Vendeia. Mas o cenário do romance Noventa e três é, principalmente, a Bretanha, situada ao Norte do Loire, em frente ao Sudeste da Inglaterra. Como as outras monarquias do continente europeu, a Inglaterra tinha iguais razões, senão maiores, para apoiar as forças contrarrevolucionárias que lutavam pelo restabelecimento da monarquia na França. Ela tremia ao lembrar a sua experiência republicana 140 anos antes da França. Mas a questão não era apenas a de decidir entre república e monarquia: "Para se entender a Vendeia", diz o autor, "é necessário figurar-se este antagonismo: de um lado a Revolução Francesa, de outro o camponês bretão". Este, de origem celta, respeitava seu senhor em seu carrasco e falava uma língua morta, o que, para o autor, equivalia a "fazer o pensamento habitar numa tumba" (Hugo, 2001, p. 268).

Em 28 de abril a Comuna de Paris dera aos voluntários de Santerre a seguinte consigna: Nada de perdão, nada de piedade. No final de maio, dos doze mil soldados que haviam partido de Paris, oito mil já tinham sido mortos. A partir deste ponto o autor prossegue sua narrativa centrando o olhar no Batalhão do Boné Vermelho. Este, sob o comando do sargento Radoub, estava engajado na trágica floresta de Saudraie, onde a caça aos pássaros à noite dera lugar à caça aos homens. O batalhão avançava olhando sucessivamente "para a direita e para a esquerda, para a frente e para trás", tendo cada soldado "um olho nas costas". Marchava-se sempre "temendo encontrar o que se procurava” (Hugo, 2001, p. 52). 


\section{A camponesa e as três crianças}

$E$ eis que, de repente, ante o que poderia ser uma emboscada, no momento em que o sargento ia gritar fogo, a vivandeira que seguia o batalhão gritou: "Alto! [...] Não atirem, camaradas!" Lá estava uma mulher - Michelle Fléchard -, com o grosso capuz dos camponeses bretões, amamentando Georgette, com dois meninos, René-Jean e GrosAlain, dormindo ao lado. O interrogatório revelou coisas interessantes. A senhora Fléchard não soube dizer qual era a sua pátria. Mas ante a insistência do sargento para que declarasse de onde era, esclareceu: "Eu compreendo, senhor. O senhor é da França, eu sou da Bretanha." Informou ainda que estava ali porque sua casa fora queimada. Sabia de onde vinha, mas não sabia para onde ia. Quanto a seus antepassados, seu pai esclareceu a camponesa - "estava enfermo e não podia trabalhar por conta das bastonadas que o senhor, seu senhor, nosso senhor, lhe havia mandado dar, o que era uma bondade, porque seu pai tinha se apossado de um coelho." Disse que por essa razão ele fora condenado à morte, mas que o senhor lhe tinha concedido graça e havia dito: "Dêem-lhe somente cem golpes de bastão", o que o deixara estropiado. Seu avô era huguenote, e o vigário conseguira que o enviassem às galeras, quando ela ainda era pequena. O seu sogro era falso salineiro, e o rei o mandara enforcar. Seu marido, dias antes, tinha se batido, em combate, pelo rei, pelo seu senhor e pelo cura. A manifestação de indignação de um granadeiro provoca um "sobressalto de pavor" na senhora Fléchard. A vivandeira intervém para tranqüilizar a camponesa bretã: "A senhora vê, nós somos parisienses" (Hugo, 2001, p. 54-61).

Finalmente, respondendo à pergunta sobre o que seu marido fazia, sobre o que se havia tornado, a bretã esclareceu: "Ele não se tornou nada, porque o mataram." Isto, havia apenas três dias. Mas ela não sabia quem o tinha matado, se tinha sido um azul (revolucionário republicano) ou um branco (contrarrevolucionário realista). Sabia que fora com um tiro de fuzil. Ao final do interrogatório, o sargento tirou do bolso um pedaço de pão e o alcançou à mãe, que o partiu e deu aos meninos, que o "morderam com avidez". O sargento providenciou pão também para a mãe e água para ela e as crianças. Estavam aí, diz Victor Hugo, "Uma viúva, três órfãos, a fuga, o abandono, a solidão, a guerra ribombando em toda a volta do horizonte, a fome, a sede, como único alimento o capim, como único teto o céu." Por fim, levantando a voz, o sargento Radoub proclamou: "Camaradas, tudo isto indica que o batalhão vai tornar-se pai. Está combinado? Nós adotamos essas três crianças. [...] as crianças do Batalhão do Boné Vermelho." E dirigindo-se à mãe: "Venha, cidadã " (Hugo, 2001, p. 61).

\section{A contrarrevolução tem um chefe}

Em primeiro de junho de 1793, da pequena baia deserta de Bonnenuit, na ilha britânica de Jersey, parte uma corveta, levando um homem alto, ereto, robusto e de ar severo, com toda a pinta de estar entrando numa aventura. Da outra parte já fora expedida ordem de advertir a marinha francesa e de capturar a corveta e guilhotinar um homem descrito como sendo de "estatura alta, velho, cabelos brancos, traje de camponês, mãos de aristocrata". É significativo o diálogo travado entre o comandante e o

\footnotetext{
7 No dia seguinte à proclamação da República, 22 de setembro de 1792, o título de cidadão passou a substituir legalmente aqueles de meu senhor e senhor (Hugo, 2001, p. 67, nota 1). Hist. Educ. [Online] Porto Alegre v. 20 n. 48 Jan./abr., 2016 p. 281-302
} 
subcomandante da corveta, cujas palavras o vento espalhava nas trevas. O comandante: "Vamos ver se é um chefe." E o subcomandante: "Enquanto isto, é um príncipe." E a seguir: "Já é tempo de se ter um chefe. Concordo com Tinténiac: um chefe e pólvora! [...] eu conheço quase todos os chefes possíveis e impossíveis: os de ontem, os de hoje e os de amanhã; nenhum deles é a cabeça de guerra de que precisamos." E prosseguiu: "A esta hora, nesse exército de camponeses, há heróis, mas não há capitães. [...] Para que serve disputar a revolução e que diferença existe entre os republicanos e nós, se nós colocamos os fidalgos sob o comando dos cabeleireiros?" Não bastava ser fidalgo. Havia que ser bom. Isto é, feroz. Afinal, esta era uma "guerra sem misericórdia" (Hugo, 2001, p. $69)$.

Um acidente com um canhão que se desprendera das amarras danificou gravemente a corveta. Daí o anúncio do comandante:

O homem que está conosco representa o rei. Ele nos foi confiado, nós o temos que salvar. Ele é necessário ao trono da França; na falta de um príncipe, ele será, é a nossa expectativa, o chefe da Vendeia. É um grande oficial de guerra. Ele devia chegar à costa da França conosco; agora é preciso que ele chegue sem nós. Salvar a cabeça é salvar tudo. (Hugo, 2001, p. 108)

Por isso a escolha de um "marinheiro forte, bom remador e bom nadador" e, também, "que seja da região e que conheça os caminhos". Finalmente, apesar de toda a vigilância dos navios da esquadra francesa, o marquês de Lanténac (era este o nome do misterioso passageiro da fragata), alcança o litoral francês (Hugo, 2001, p. 101), de onde despacha imediatamente o marinheiro Halmalo, com a seguinte incumbência:

- Dirás isto aos chefes [...] Prefiro a guerra das florestas à guerra das planícies; não me interessa alinhar cem mil camponeses sob a metralha dos soldados azuis e sob a artilharia do senhor Carnot; antes de um mês eu quero quinhentos mil matadores emboscados na floresta. $O$ exército republicano é meu coelho. Caçar ilegalmente é guerrear. Eu sou o estrategista do mato. Bem, eis uma palavra que tu não escolherás, ou então, tu escolherás isto: Nada de piedade, e emboscadas por toda a parte. Eu quero fazer mais de Chouannerie ${ }^{8}$ do que de Vendeia. Dirás também que os ingleses estão conosco. Vamos colocar a república entre dois fogos. A Europa nos ajuda. É preciso acabar com a revolução. Os reis Ihe fazem a guerra dos reinos, façamos-lhe a guerra das paróquias. Tu dirás isto. Compreendeste? (Hugo, 2001, p. 128)

Halmalo não sabia ler, o que era uma vantagem, porquanto, para Lanténac, "um homem que lê pode criar embaraço." Poderia ler o cartaz que condenava Lanténac à morte, assinado também pelo comandante Gauvain, seu sobrinho-neto!. Bastava, por isso, que tivesse boa memória. (Hugo, 2001). A resposta de Halmalo revela que, mais que boa memória, o que ele tinha era grande capacidade de síntese:

\footnotetext{
${ }^{8}$ Movimento dos chouans, rebeldes do oeste da França em luta pelo restabelecimento da monarquia. Hist. Educ. [Online] Porto Alegre v. 20 n. 48 Jan./abr., 2016 p. 281-302
} 
- Sim. É preciso levar tudo a fogo e sangue.

- É isto.

- Sem piedade.

- A ninguém. É isto. (Hugo, 2001, p. 128)

\section{O Batalhão do Boné Vermelho é surpreendido}

Tendo passado a noite no abrigo do mendigo Tellmarch, que o reconhecera, o marquês de Lanténac, já a caminho, tem sua atenção despertada por uma fuzilaria intensa numa granja. Era uma multidão de insurgentes que se defrontava com o Batalhão do Boné Vermelho. Cessado o tiroteio, ouvem-se gritos: "Lanténac, Lanténac, o marquês de Lanténac!" Era une bande vendéenne, diz o autor. Eram sete mil, informava o jovem que entregara a Lanténac a bandeira tomada aos azuis, mas logo haveriam de ser quinze mil (Hugo, 2001). Fizeram-se ouvir, então, as ordens do general: que se dispersassem e se dirigissem para a floresta de Fougères que, uma vez que os habitantes d'Herbe-en-Pail haviam recebido bem os azuis, não bastava que se tivesse queimado a granja, que se queimasse também o vilarejo. $E$ no que respeitava às bestas ferozes do Batalhão do Boné Vermelho: quanto aos feridos, que se terminasse o serviço; quanto aos prisioneiros, que fossem fuzilados; quanto às mulheres, que fossem fuziladas da mesma forma; quanto às crianças, que fossem levadas: "A gente verá o que fazer com elas" (Hugo, 2001, p. 158).

Com a atenção atraída pela fumaça, o mendigo Tellmarch dirige-se lentamente na direção d'Herbe-en-Pail. Não havia mais nem granja nem vilarejo. Um montão de casebres queimando: "Há algo mais doloroso do que ver-se queimar um castelo: é ver-se queimar uma choupana. Uma choupana em fogo é lamentável. A devastação abatendo-se sobre a miséria, o abutre abatendo-se sobre o verme da terra: há ali não se sabe que contra-senso que corta o coração" (Hugo, 2001, p. 15).

Mas o pior não fora visto ainda: um monte de cadáveres no pátio da granja já sem muro. Prisioneiros fuzilados. Ninguém se dera ao trabalho de enterrá-los. E duas mulheres: uma vivandeira, morta com quatro tiros na cabeça, e uma camponesa, com a clavícula quebrada por uma bala, ainda viva. Apenas dois sobreviventes: dois camponeses que se haviam escondido (Hugo, 2001, p. 160-162). E um deles declara que

Todos os outros estão mortos, não é? Eu vi isto. Eu estava na minha toca. Como a gente agradece a Deus num momento como este por não ter família! Minha casa estava queimando. Senhor Jesus! Esta mulher tinha crianças. Três crianças, bem pequenas! As crianças gritavam: Mãe! A mãe gritava: Meus filhos! Mataram a mãe e levaram as crianças. Eu vi isto, meu Deus! Meu Deus! Meu Deus! Aqueles que arrasaram tudo partiram. Estavam contentes. Eles levaram as crianças e mataram a mãe. Mas ela não está morta, não é? ela não está morta. Diga, pois, mendigo, você acredita que poderá salvá-la? Quer que o ajudemos a levá-la para a sua toca (carnichot $\left.{ }^{9}\right)$ ? (Hugo, 2001, p. 162)

${ }^{9}$ Carnichot: buraco grande, cavado sob uma árvore, coberto por seus ramos. Hist. Educ. [Online] Porto Alegre v. 20 n. 48 Jan./abr., 2016 p. $281-302$ 
E enquanto carregavam a mulher ferida para a floresta, comentavam: "Matar tudo! Queimar tudo! Ah! Senhor Deus! Será que vai ser assim agora? Foi esse velho que quis assim. Sim, era ele que comandava. [...] É o senhor Lanténac." O mendigo levanta os olhos para o céu e murmura: "Se eu tivesse sabido!" (Hugo, 2001, p. 162).

\section{O ex-mestre Cimourdain para vigiar o ex-discípulo Gauvain}

Enquanto isso, no dia 28 de junho, em Paris, um cão de guarda recebera ordem de Marat de não deixar ninguém entrar no local onde ele se reunia com Danton e Robespierre. Para Danton só havia uma urgência: a República em perigo. Os três líderes tinham consciência de que a guerra de floresta estava sendo organizada em vasta escala e de que o exército republicano estava dizimado. "Em quinze dias - diz Robespierre - se terá formado um exército de trezentos mil homens, e toda a Bretanha estará com o rei da França". Ao que Danton acrescenta: "Quer dizer o rei da Inglaterra". E Robespierre: "O rei da França é pior. Bastam quinze dias para enxotar os estrangeiros, e precisa-se de dezoito séculos para acabar com a monarquia" (Hugo, 2001, p. 199) Falam, a seguir, de um jovem comandante que, sem autorização do comando Lechelle, não dava trégua a Lanténac. Mas ele tinha um defeito: a clemência. Decidem então, de comum acordo, enviar o ex-padre Cimourdain, que os surpreendera entrando pela porta dos fundos, para vigiar o comandante Gauvain:

ANO II DA REPÚBLICA. Plenos poderes são dados ao cidadão Cimourdain, comissário delegado do Comitê de Saúde Pública junto ao cidadão Gauvain, comandante da Coluna Expedicionária do Exército das Costas. Robespierre - Danton - Marat. 28 de junho de 1993. (Hugo, 2001, p. 222).

Assim, o ex-padre e ex-mestre Cimourdain é mandado vigiar o ex-discípulo Gauvain, agora comandante republicano enfrentando seu tio-avô, o realista marquês de Lanténac.

\section{Camponeses contra patriotas}

Já se disse acima que, para se entender a Vendeia, é necessário ter diante de si o antagonismo entre a Revolução Francesa e o camponês bretão. Victor Hugo assim descreve a região em que se travou a guerra entre cidade e campo: "Havia então na Bretanha sete florestas horríveis. A Vendeia é a revolta-padre (la révolte-prêtre). Essa revolta teve como auxiliar a floresta." E complementa: "As trevas se ajudam mutuamente" (Hugo, 2001, p. 267).

Para o autor o camponês bretão tinha dois pontos de apoio: o campo, que o alimentava, e a floresta, que o escondia. A vida subterrânea era imemorial na Bretanha:

Uns depois dos outros, os trogloditas para escapar dos celtas, os celtas para escapar dos romanos, os bretões para escapar dos normandos, os huguenotes para escapar dos católicos, os contrabandistas para escapar dos fiscais, se haviam refugiado primeiro nas florestas, depois debaixo da terra. [...] As trágicas florestas bretãs retomaram seu velho papel e se tornaram auxiliares e cúmplices desta revolta, como elas o haviam sido em todas as outras. (Hugo, 2001, p. 270-271) 
A Vendeia insurgida tinha pelo menos meio milhão de combatentes: homens, mulheres e crianças, mas, segundo a avaliação do autor, esse grande exército católico foi um esforço insensato, um desastre previsível, como que "uma tempestade camponesa atacando Paris, uma coalizão de vilarejos assediando o Panteão". Para ele: "A verdadeira Vendeia é a Vendeia em casa [chez elle]; lá ela é invulnerável, ela é inexpugnável." Fora de seu chão, porém, ela não passava de um aborto. As palavras pays, patrie (localidade, pátria) resumiam toda a Guerra da Vendeia: "querela da idéia local contra a idéia universal; camponeses contra patriotas." Foi assim que a Vendeia acabou com a Bretanha, essa "velha rebelde", que sempre teve razão, menos na última revolta, quando quis fazer "a guerra do espírito local contra o espírito central" (Hugo, 2001, p. 283).

\title{
O sobrinho-neto Gauvain bate o tio Lanténac
}

$\mathrm{Na}$ entrada de Pontorson, a caminho de Dol, o estalajadeiro, em conversa com um homem recém-chegado, que parara para descanso e alimentação do cavalo, fez descrição precisa do que se passava:

\begin{abstract}
Veja, cidadão; a situação é esta. Nas cidades e nos burgos maiores, nós somos pela revolução, no campo eles são contra; é o mesmo que dizer que nas cidades se é francês e que nas aldeias se é bretão. É uma guerra de burgueses contra camponeses. Eles nos chamam de patauds (moleirões), nós os chamamos de rustauds (grossos). Os nobres e os padres estão com eles. (Hugo, 2001, p. 295)
\end{abstract}

"Nem todos", contesta o ex-padre Cimourdain. "Sem dúvida, cidadão," acrescenta o estalajadeiro, "uma vez que nós temos aqui um visconde contra um marquês." $E$ esclarece ainda que o visconde Gauvain cortara pela raiz o plano de Lanténac, assumindo o controle da costa e empurrando-o para o interior e os ingleses para o mar, que ele manobrava para empurrar o marquês para a floresta de Fougères e ali pegá-lo, que tudo ia bem até a véspera, mas que se sabia agora que Lanténac estava a caminho de Dol, buscando o controle do Monte Dol, de onde apoiaria o desembarque das forças inglesas. Com esta informação, Cimourdain pôs-se novamente a caminho, seguindo não à direita, como lhe aconselhara o estalajadeiro, mas à esquerda, rumo a Dol, distante cerca de três horas a cavalo (Hugo, 2001, p. 295-299).

Gauvain bate Lanténac, mais pela esperteza do que pela força, impedindo-o assim de assumir o controle do monte Dol e, com isso, inviabilizando o desembarque de soldados ingleses - ideia fixa do comandante realista. Este não acreditava muito na guerra de guerrilha, que "não conclui nada ou conclui mal"; que "começa por atacar uma república e termina por destruir uma diligência". A força camponesa era útil, sim, para o ataque, a emboscada e a surpresa, mas era muito fluida, como a "água em sua mão". Lanténac "queria juntar ao exército selvagem das florestas uma tropa regular que fosse o pivô de manobra dos camponeses." Força esta que só poderia vir da Inglaterra (Hugo, 2001, p. 299).

$\mathrm{Na}$ batalha em Dol, Cimourdain chega a tempo de salvar a vida de Gauvain, mas sai ferido. O caso mais grave, porém, era o da senhora Fléchard, mãe das três crianças, que ficara aos cuidados do mendigo Tellmarch, clamando pelas suas crianças levadas por Lanténac (Hugo, 2001). 


\section{Qual república?}

A guerra continuava, mas a Vendeia ia perdendo terreno. Sobreviera, porém, uma complicação singular:

Em toda esta parte da Vendeia, a república estava por cima, o que estava fora de dúvida; mas qual república? No triunfo que se esboçava, duas formas de república estavam presentes: a república do terror e a república da clemência; uma querendo vencer pelo rigor, a outra pela doçura. Qual haveria de prevalecer? Essas duas formas, a forma conciliadora e a forma implacável, estavam representadas por dois homens, cada um tendo sua influência e sua autoridade, um comandante militar, o outro delegado civil. (Hugo, 2001, p. 328)

Essa guerra surda entre esses dois homens não podia deixar de estourar. Numa certa manhã foi Cimourdain quem iniciou a batalha:

- Onde estamos?

Gauvain respondeu:

- O senhor sabe tão bem como eu. Eu dispersei os bandos de Lanténac. Ele não tem com ele mais do que alguns homens. Ei-lo empurrado para a floresta de Fougères. Dentro de oito dias, ele estará cercado.

- E em quinze dias?

- Ele estará preso.

- E depois?

- O senhor viu meu edital?

- Sim. E então?

- Ele será fuzilado.

- Ainda clemência. É preciso que ele seja guilhotinado.

- Eu, diz Gauvain, sou pela morte militar.

- E eu, retrucou Cimourdain, sou pela morte revolucionária. (Hugo, 2001, p. 329)

E fixou o olhar em Gauvain, inquirindo por que este havia posto em liberdade um grupo de religiosas quando era sabido que uma mulher com ódio vale por dez homens, por que se havia recusado a enviar ao tribunal revolucionário "toda essa tropa de padres fanáticos presos em Louvigné", quando é sabido que uma rebelião "é mais perigosa quando pregada por cabelos brancos". Ao que Gauvain respondeu tranquilamente: "Eu não faço guerra às mulheres. [...] Eu não faço guerra aos velhos." Disse ainda o comandante que teria deixado o delfim fugir, que não fazia guerra às crianças. Ao que the retrucou Cimourdain, com olhar severo: "Gauvain, saiba que é necessário fazer a guerra à mulher quando ela se chama Maria Antonieta, ao velho quando ele se chama Pio VI, papa, e à criança quando ela se chama Louis Capet ${ }^{10}$." Perguntou ainda por que Gauvain tinha impedido a coluna de matar o rebelde Jean Treton, acossado e perdido, e por que, tendo chamado a si a responsabilidade, dera um tiro para o alto, em vez de matar o valdeen Bézier, ferido. Ao que Gauvain respondeu: "Porque não se põe mil e quinhentos soldados a matar um homem" e "não se mata um homem caído por terra." Na realidade, a questão de fundo era outra: "Se você prender Lanténac, você o perdoará? [...] Lanténac é seu parente. Lanténac é um velho" (Hugo, 2001, p. 330). 
E Gauvain: "Liberdade, Igualdade, Fraternidade, estes são dogmas de paz e de harmonia. Por que dar-Ihes um aspecto assustador? O que queremos nós? Conquistar os povos para a república universal. Pois bem, não thes façamos medo. Para que serve a intimidação?" E completa: "Abatamos as coroas, poupemos as cabeças." E Cimourdain: "Tome cuidado [...], Gauvain, você é para mim mais que um filho, tome cuidado." Quem tivesse ouvido esses dois homens falando, observa Victor Hugo, teria acreditado estar ouvindo "o diálogo entre a espada e o machado" (Hugo, 2001, p. 334).

\section{A Dolorosa}

Sob o título Dolorosa o autor fala da mãe, Michelle Fléchard, à procura de seus filhos. Como já se viu ela tinha sido acolhida e assistida, em seu restabelecimento, pelo mendigo Tellmarch, lá em sua toca na floresta. Agora, diz o autor, "ela andava à frente dela mesma". "Vá à Tourgue" (Torre Gauvain), disseram-Ihe. "Para o lado de Fougères. [...] na direção do por do sol. [...] Mas cuidado. Combate-se por lá.", recomendou-lhe um camponês (Hugo, 2001, p. 34).

Com efeito, Lanténac, acossado por Gauvain, refugiara-se na Tourgue com alguns de seus combatentes. $E$ as três crianças. Referindo-se ao marquês e ao ex-padre, o autor diz: "A marca de bronze da guerra civil tem dois perfis: um voltado para o passado, outro voltado para o futuro; mas tão trágicos um como o outro" (Hugo, 2001, p. 357).

Finalmente, Cimourdain tinha Lanténac em sua mão. Foi por isso que mandara procurar em Fougères a guilhotina que fora vista a caminho: "Matar Lanténac era matar a Vendeia; matar a Vendeia era salvar a França. Cimourdain não hesitava. Este homem sentia-se à vontade na ferocidade do dever" (Hugo, 2001, p. 406).

Sem condições de enfrentar as forças comandadas pelo sobrinho Gauvain, Lanténac mandara que os poucos combatentes que estavam na Tourgue fugissem para a floresta, inclusive Halmalo. Ele, carregando no bolso a pesada chave da porta de ferro batido que impedia a entrada, estava para retirar-se quando ouviu o grito desesperado da mãe pedindo que salvassem seus filhos do fogo que tomava conta da Tourgue. Impossível, para os homens de Gauvain, subir para o andar onde estavam as crianças: não havia escada e não se conseguia abrir a porta de ferro. Para surpresa geral, de repente o próprio Lanténac estende lá de cima uma longa escada, que Radoub recebe ao grito de "Viva a República!", seguido de um "Viva o rei!" Alcançadas por Lanténac as três crianças chegam, uma a uma, até o pé da escada. À chegada do marquês, Cimourdain o declara preso e, voltando-se para Gauvain, informa que vai convocar a corte marcial, da qual ele, Gauvain, não poderia fazer parte, uma vez que Lanténac também era Gauvain (Hugo, 2001, p. 461).

Enquanto isso, Gauvain dizia para si mesmo: "Esta cabeça, ele a devia. Assim, ele a pagava. Isso é tudo." Uma dúvida, no entanto, o assaltava: "Mas era exatamente a mesma cabeça?" Afinal: "Um Lanténac entrava em cena. [...] Um herói surgia do monstro; mais que um herói, um homem. [...] Três crianças estavam perdidas; Lanténac as havia salvado." É verdade que ele mesmo tinha construído o crime, mas ele tinha recuado: "O grito da mãe tinha despertado nele esse fundo de velha piedade humana. [...] Diante desse grito, ele tinha retornado sobre seus passos" (Hugo, 2001, p. 470).

Gauvain surpreende Lanténac no cárcere. Ao final da conversa ele o liberta, assumindo o seu lugar. 


\section{Novo diálogo sobre qual república}

Preso no cárcere de onde soltara Lanténac, Gauvain recebe a visita de seu exmestre Cimourdain, que vai tomar a sopa com ele. Recolhem-se aqui alguns aspectos do diálogo entre a espada e o machado, como diz Victor Hugo. Gauvain começa por salientar as diferenças entre a república almejada por ele e aquela defendida por Cimourdain: "Acima da balança, há a lira. A república que o senhor quer dosa, mede e regula o homem; a minha o eleva para o azul pleno; eis a diferença que existe entre um teorema e uma águia" (Hugo, 2001, p. 504). Para Cimourdain basta dar a cada um o que the cabe. $E$ justifica: "A república é dois e dois são quatro." Ao que Gouvain retruca: "Resta dar a cada um o que Ihe falta." O primeiro diz: "Eu não vejo outra coisa que a justiça"; e o segundo: "Eu olho para mais alto" (p. 506).

Gauvain e Cimourdain divergiam não só quanto à república por que lutavam, mas também sobre os três temas anunciados: do camponês, da mulher e da criança. É o que se verá agora.

\section{Diálogo sobre o camponês}

Quanto ao camponês, Gauvain sustenta que três quartas partes do solo francês não são cultivadas. Ele defende "que todo homem tenha uma terra, e que toda a terra tenha um homem", com o que se centuplicaria produção. Defende ainda que se utilize a natureza, inclusive o oceano. Para o ex-mestre Gauvain não passava de um sonhador. (Hugo, 2001, p. 506)

$\mathrm{Na}$ Bretanha ainda feudal a relação com a terra - ter ou não ter terra, ser senhor ou ser servo - constituía-se não só numa diferença, mas numa diferença que se traduzia em imensa desigualdade. Baste lembrar o destino do pai da senhora Fléchard, inutilizado para o trabalho em consequência das cem bastonadas a que o senhor o condenara por se haver apossado de um coelho.

Outro ponto importante a salientar é a oposição radical entre campo e cidade presente em toda a narrativa de Noventa e três, oposição esta de interesses tão bem descrita por Karl Marx em A ideologia alemã: "A divisão do trabalho no interior de uma nação leva, inicialmente, à separação entre o trabalho industrial e comercial, de um lado, e o trabalho agrícola, de outro, e, com isto, à separação da cidade e do campo e à oposição de interesses entre ambos." (Marx, 2007, p. 89). Esta oposição e luta entre cidade e campo constituem o núcleo da narrativa de Victor Hugo, e o enfrentamento entre a Tourgue e a guilhotina é a sua expressão mais dramática.

No entanto, o que se acaba de dizer não quer significar que a interpretação de Victor Hugo sobre a relação cidade-campo coincida com a interpretação inspirada em Marx. Bastaria a leitura de O dezoito brumário de Luís Bonaparte (Marx, 1997) para certificar-se disto $^{11}$. O que se afirma é que o autor de Noventa e três se aproxima de figuras dentre as mais expressivas daquilo que por vezes se chamou de liberalismo social, como Condorcet, John Dewey e John Maynard Keynes, todos acusados de socialismo pelas diferentes formas de ultraliberalismo, entre elas, o neoliberalismo (Ferraro, 2005).

\footnotetext{
${ }^{11}$ Marx (1997, p. 13) diz que Victor Hugo, ao ver no golpe de Estado de 1851 "apenas o ato de força de um indivíduo", acaba por engrandecer Luís Napoleão, "atribuindo-Ihe um poder pessoal de iniciativa sem paralelo na história do mundo". Hist. Educ. [Online] Porto Alegre v. 20 ก. 48 Jan./abr., 2016 p. 281-302
} 


\section{Diálogo sobre a mulher}

Por sua vez, o diálogo sobre a mulher é particularmente revelador do confronto havido ao tempo da Revolução Francesa sobre o papel e o lugar mulher na recém criada República. Para Cimourdain não podia haver igualdade entre seres diferentes, entre seres que não tivessem a mesma identidade. Para Gauvain, ao contrário, o fato de a mulher e o homem serem diferentes significava apenas que não eram idênticos, não que não pudessem ser iguais. É ele novamente que toma a iniciativa:

- E a mulher? O que o senhor faz dela?

Cimourdain respondeu:

- Aquilo que ela é. A servidora do homem.

- Sim. Com uma condição.

- Qual?

- Que o homem seja o servidor da mulher.

- Você pensa isto? exclamou Cimourdain, o homem servidor! Jamais. O homem é senhor. Eu admito uma única realeza, aquela do lar. Ali o homem é rei.

- Sim. Com uma condição.

- Qual?

- Que a mulher seja a rainha.

- Quer dizer que você quer para o homem e para a mulher...

- A igualdade.

- A igualdade! você sonha? Os dois seres são diferentes.

- Eu disse igualdade. Eu não disse identidade. (Hugo, 2001, p. 507)

O diálogo acima transcrito traduz o conflito existente já ao tempo da Revolução Francesa sobre a relação entre igualdade e diferença no tocante às relações de gênero. $A$ propósito, em estudo sobre as feministas francesas no período que vai da Revolução Francesa ao final da Segunda Guerra Mundial, Scott (2002) refere-se repetidamente à especificidade histórica dos paradoxos, das contradições, dos dilemas envolvidos na relação entre igualdade e diferença. A autora sustenta que enfoques antagônicos têm tomado partido em favor de duas tendências opostas no que concerne à conceituação de indivíduo de parte das feministas: "Umas têm pugnado pela corrente que considera as mulheres iguais aos homens (indivíduo abstrato) e outras pela corrente que insiste na diferença radical entre homens e mulheres (indivíduo por diferença sexual)" (Scott, 2002, p. 283).

Para ela, as feministas da igualdade, seguidoras de Simone de Beauvoir, ignoram a diferença sexual "por considerá-la irrelevante no contexto dos direitos humanos que os princípios universais da lei democrática liberal reconhecem" (Scott, 2002, p. 283). Já as feministas da diferença sustentam que a diferença sexual é um produto inevitável da individuação e que o individualismo abstrato - da igualdade -, além de reprimir a diferença sexual, estaria perpetuando a opressão da mulher, precisamente por transformar a masculinidade em norma. A autora vê nesse antagonismo entre igualdade e diferença um paradoxo, insolúvel como todo paradoxo. Conclui dizendo que as feministas jamais conseguiram resolver os dilemas com que se defrontaram, não tendo conseguido dar mais do que respostas fatalmente paradoxais. Em sua opinião, "o problema que sempre se considerou tão categórico e crucial e que ainda perdura (igualdade versus diferenças) não pode ser resolvido da maneira como tem sido apresentado" (Scott, 2002, p. 284). 
Fica, assim, a pergunta: haveria outra maneira de se enfrentar a questão do paradoxo entre igualdade e diferença a que se refere Scott? Ou, talvez: trata-se mesmo de um paradoxo?

Depois de Scott (2002), vários autores brasileiros têm abordado a questão da relação entre igualdade e diferença. Pierucci (2007), por exemplo, distingue três ondas na história do feminismo ${ }^{12}$ : o feminismo igualitarista, do final do século 19 até os entornos de1968, o feminismo diferencialista, até início da década de 1980 e, por fim, o feminismo da multiplicidade feminina, em que à diferença entre homem e mulher se teriam vindo somar as diferenças entre as mulheres. Em texto anterior, Pierucci (2008, p. 31) chamara a atenção para algo importante, a saber, que "as novas divisas de esquerda que giram em torno do direito à diferença trazem consigo um ardil": o amor da diferença ter-se-ia alimentado no campo (ultra)conservador por duzentos anos a fio, tendo sido só muito recentemente incorporado nalgumas faixas ou zonas de esquerda. Para o autor, o risco é de pessoas de esquerda, cativadas pelo charme da diferença, acabarem abrindo mão da igualdade.

Para atestar a atualidade do tema, há que registrar que o título Identidade, igualdade e diferença: o olhar da História, de um capítulo de obra de Perrot (2005), reproduz os três termos-chave do diálogo entre Gauvain e Cimourdain sobre a mulher, como se viu acima.

A análise desenvolvida sobre o tema mulher permite firmar desde já três pontos: que a questão da igualdade e diferença nas relações de gênero é atual, que o enfrentamento dessa questão tem uma longa história que não pode ser ignorada, que essa questão, longe de restringir-se a gênero, nem mesmo à tríade gênero, raça e classe, estende-se também a outras dimensões do social, como às relações cidade-campo e entre gerações, como se verá adiante.

\section{Diálogo sobre a criança}

Como se acaba de dizer, o desafio da articulação entre igualdade e diferença não se limita às relações campo-cidade e de gênero. Atinge também as relações entre gerações, com destaque para o que os adultos querem para a criança. É Cimourdain, agora, quem toma a iniciativa:

- E a criança! A quem você a dá?

- Primeiro ao pai que a gera, depois à mãe que a cria, depois ao mestre que a educa, depois à cidade que a viriliza, depois à pátria que é a mãe suprema, depois à humanidade que é a grande avó.

- Você não fala de Deus.

- Cada um desses degraus, pai, mãe, mestre, cidade, pátria, humanidade, é um dos degraus da escada que leva a Deus. [...]

- Gauvain, retorne à terra. Nós queremos realizar o possível.

- É preciso começar por não torná-lo impossível. [...]

Gauvain continuou:

- Oh! Mestre, eis a diferença entre as nossas duas utopias. O senhor quer a caserna obrigatória, eu quero a escola obrigatória. O senhor sonha com o homem soldado, eu sonho com o homem cidadão. O senhor o quer terrível, eu o quero pensante. O senhor funda uma república de espadas,

12 Antes do texto de Pierucci, Sowerwine e Grimshaw (2006), num texto sobre igualdade e diferença no século 20 em países ocidentais, haviam também discutido as três ondas do feminismo. 
eu fundo ...

Ele se interrompeu:

- Eu fundarei uma república de espíritos. [...]

Decorreu certo tempo assim. Cimourdain perguntou-lhe:

- Em que você está pensando?

- No futuro, disse Gauvain.

E ele mergulhou novamente em sua meditação. (Hugo, 2001, p. 508)

Decorrido quase um século desde a Revolução Francesa e menos de uma década da publicação de Noventa e três, com as leis Jules Ferry a Terceira República estabeleceria, na França, o ensino público, gratuito, obrigatório e laico, para ambos os sexos (leis de 1881 e 1882). Essa legislação haveria de servir de inspiração, por exemplo, para a Lei de Educação Comum na República Argentina, a lei n. 1.420, de 1884 (Argentina, 1984). No Brasil o liberalismo dominante no final do Império e República adentro faria com que tivéssemos que esperar por mais meio século para termos uma legislação educacional semelhante.

Cury ressalta que a articulação entre igualdade e diferença se constitui num desafio também quando a atenção se volta para a geração jovem. Tratando do direito à educação ele sustenta algo que é ao mesmo tempo esclarecedor e desafiador no que se refere a tal direito: "A dialética entre o direito à igualdade e o direito à diferença na educação escolar como dever do Estado e direito do cidadão não é uma relação simples" (Cury, 2007, p. 255).

Quanto a esta afirmação de Cury há duas considerações a fazer. A primeira é que ao dizer que a relação entre igualdade e diferença não é uma relação simples, ele acompanha Scott $(2005$, p. 12), para quem "não existem soluções simples para as questões, debatidas calorosamente, da igualdade e da diferença, dos direitos individuais e das identidades de grupo". A segunda consideração, no entanto, refere-se ao fato de que, para Cury, a relação entre direito à igualdade e direito à diferença é uma relação dialética.

Se a perspectiva da igualdade e da diferença identificada por Scott em seus estudos do feminismo se configura mais como dilema ou paradoxo sem solução, Cury, na sequência do texto citado, sustenta não só a possibilidade, mas também a necessidade de articulação das duas perspectivas. De um lado, segundo ele, não se pode abrir mão da "defesa da igualdade como princípio de cidadania, da modernidade e do republicanismo", afinal, a igualdade, ao mesmo tempo em que é princípio da não discriminação, é o foco da luta em prol da eliminação dos privilégios de sangue, etnia, religião ou crença, mas, de outro lado, tem-se a heterogeneidade, que é visível, sensível e imediatamente perceptível, diferentemente do que se tem em relação ao princípio abstrato da igualdade. $E$ adverte: "A defesa das diferenças, hoje tornada atual, não subsiste se levada adiante em prejuízo ou sob a negação da igualdade" (Cury, 2007, p. 255).

Ora, dizer que a relação entre igualdade e diferença é uma relação dialética equivale a dizer, de um lado, que ela contém contradições e, de outro, que a síntese que possa resultar desse movimento dialético não será nunca uma superação definitiva das contradições. Quase a dizer que a articulação entre os dois termos contraditórios da relação - igualdade e diferença - só poderá ser alcançada na luta política e pedagógica de quantas e quantos tenham visto e enfrentado a situação de alguma diferença transformada em desigualdade, nunca por passes de magica. 


\section{Desfecho da guerra: a guilhotina contra Tourgue}

Ao despontar do dia, uma "coisa estranha, imóvel, surpreendente, e que as aves do céu não conheciam", apareceu junto à Tourgue - a guilhotina. "Na Tourgue - diz Victor Hugo - se concentravam quinze séculos: a idade média, a vassalagem, a gleba, a feudalidade; na guilhotina, um ano - 93; e esses doze meses faziam contrapeso a esses quinze séculos. [...] A Tourgue tinha o ar de estar examinando a guilhotina" (Hugo, 2001, p. 512).

Por mais que cinco mil soldados implorassem por graça, fez-se ouvir o golpe da lâmina da guilhotina sobre o pescoço do comandante Gauvain. Havia que dar força à lei! Mas o silêncio que se seguiu foi interrompido por um tiro de pistola, que Cimourdain desferiu contra o próprio peito. Esse conflito entre as duas concepções de república, testemunhado pela Tourgue, haveria de atravessar os dias, os anos e os séculos por vir.

Sobreviveu Michelle Fléchard, a mulher camponesa, elevada pelo sargento Radoub à condição de cidadã, ficando a idéia da possibilidade de se articular diferenças - mulher e camponesa - com igualdade.

Sobreviveram também as três crianças camponesas, certamente com expectativa mais promissora, inclusive de escola, tanto para meninos, quanto para meninas.

Mas a disputa entre as duas utopias republicanas em confronto no romance Noventa e três - a caserna obrigatória e a escola obrigatória - fazem lembrar as palavras de Victor Hugo ao editor da tradução italiana de Les miserables, em 1862:

Onde esta o vosso exército de mestres de escola, o único exército que reconhece a civilização? Onde estão as escolas gratuitas e obrigatórias? Todo mundo sabe ler na pátria de Dante e de Miguel Ângelo? Não tendes vós, como nós, um orçamento de guerra opulento e um orçamento do ensino irrisório? (Hugo, 2000a, v. II, p. 1.950)

Pena não estivesse mais aí Victor Hugo para repetir essas mesmas palavras quando da publicação da nova versão brasileira de Les miserables (Hugo, 2002b).

Também não há como ignorar a persistência da dramática oposição entre cidade e campo registrada em Noventa e três, personificada na guerra de extermínio entre a cidade - Paris - e o campo - Vendeia. Nesse sentido, penso que é correta a interpretação de Euclides da Cunha quando, decorrido um século desde a Vendeia francesa, chamou a Guerra de Canudos (1896-1897) de "A nossa Vendeia" (Cunha, 2000, p. 43). Entenda-se: a nossa guerra de extermínio, a nossa guerra da cidade contra o campo. Caberia apenas ressalvar e ressaltar que o que o movimento liderado por Antônio Conselheiro ameaçava, no final do século 19, no Brasil, não era a República recém-estabelecida, mas sim o coronelismo e a sua base, o latifúndio, em que se assentavam tanto a economia, quanto a política do país, numa forte aliança entre as novas elites urbanas e os velhos e poderosos coronéis do interior.

A questão é saber se o romance Noventa e três, de Victor Hugo, oferece algum elemento que possa contribuir para a compreensão, no plano do conhecimento, e para o enfrentamento, no plano das políticas e práticas sociais, das contradições presentes na relação entre igualdade e diferença, relação esta que Lavalle (2003) tem como tema espinhoso. 
Como se viu no decorrer do texto, para Cimourdain a oposição entre igualdade e diferença é insuperável: sendo seres diferentes, mulher e homem não podem ser iguais entre si. Gauvain, no entanto, nega o pressuposto de seu ex-mestre e aponta noutra direção: "Eu disse igualdade. Eu não disse identidade." Ele estaria evitando, assim, aquilo que Lavalle (2003, p. 82) chama de "riscos da sinonímia entre igualdade e homogeneidade". Interpretando: igualdade não é o mesmo que identidade, por isso, mesmo não sendo nem podendo ser idênticos, diferentes podem ser iguais. Na concepção de república defendida pelo jovem comandante Gauvain, é possível articular entre si igualdade e diferença: no plano teórico, como se infere das próprias palavras de Gauvain: "Eu disse igualdade. Eu não disse identidade"; no plano prático, atentando para as palavras do sargento Radoub, primeiro, aos soldados do Regimento do Boné Vermelho: "Camaradas [...] Nós adotamos essas três crianças" (Hugo, 2001, p. 66) e, depois, à mulher-mãe-camponesa: "Venha, cidadã" (p. 67).

\section{Pode a lenda completar a história da educação?}

Conclui-se o artigo concordando com Victor Hugo quando diz que a lenda pode complementar a história. No caso, a história da educação. Alguns exemplos sobre o significado e os usos da leitura e da escrita, bem sobre os processos de aprendizagem dessas técnicas e as barreiras que lhe impedem ou dificultam o acesso, atestam a pertinência e a atualidade desse ponto de vista.

De um lado não se encontraria num romance a seguinte afirmação de um historiador dos usos da alfabetização na Itália moderna: "A Igreja estava presa a um dilema clássico: teria um problema se incentivasse a difusão da alfabetização e, outro, se não o fizesse" (Burke, 1995, p. 29). Nem esta outra: "De muitas maneiras, a alfabetização facilitou o controle que o Estado exercia sobre seus súditos, da mesma forma que ocorreu com a Igreja em relação ao seu rebanho. [...] A alfabetização também podia servir à causa da heresia e do protesto político" (p. 34).

De outro lado, não se imagina que possam brotar da pena de um historiador as palavras que o próprio Victor Hugo, alguns anos antes de Noventa e três, em Os miseráveis colocara na boca do líder insurgente Combeferre, em discurso proferido do alto do estoico auditório - a barricada:

As mulheres, as pobres mulheres! Não têm o hábito de pensar suficientemente em sua sorte, confiantes por saber que elas não receberam a mesma educação que os homens; impedem-nas de ler, impedem-nas de pensar, impedem-nas de tratar de política; mas quem as impedirá de ir hoje ao necrotério para reconhecer o cadáver de vocês? (Hugo, 2002b, II, p. 540).

Outro exemplo está na situação descrita no já referido romance $O$ sol é para todos, em que a autora faz brotar da pena da protagonista do romance, ex-aluna da professora Caroline, recém-saída da faculdade e ávida de aplicar o Método Decimal Dewey, as seguintes palavras: "E quando [a professora] descobriu [...] que eu fora alfabetizada, olhou-me com algo mais do que uma leve antipatia e mandou que eu dissesse a meu pai que parasse de me ensinar, pois isso atrapalharia a minha aprendizagem" (Lee, 2007, p. 27). 
E no romance $O$ caçador de pipas, o autor assim descreve a situação de dois meninos em Cabul: enquanto um, Amir, resistia em levantar cedo, para, depois do café, seguir até a escola no Ford Mustang preto do pai, o menino Hassan, que "crescera analfabeto como a maioria do hazaras" (Hosseini, 2005, p. 34), que já se havia levantado mais cedo, orado com o pai Ali, ajudado a preparar o café da manhã, arrumado o quarto de Amir, ficava em casa ajudando nas tarefas diárias "afinal, para que um criado precisaria da palavra escrita?" (p. 35).

Por fim, não seria demais lembrar as palavras que Aluísio de Azevedo (2004, p. 71), no romance $O$ mulato, de 1881, põe na boca da fofoqueira Amância Sousellas sobre o surpreendente interesse das jovens da capital do Maranhão pela leitura: "Hoje é o maquiavelismo da máquina de costura! Dá-se uma tarefa grande e é só 'zuc-zuc-zuc' e está pronto o serviço. E daí vai a sirigaita pôr-se de leitura nos jornais, tomar conta do romance ou então vai para a indecência do piano."

\section{Referências}

ARGENTINA. Ley 1420 (1883-1884). Estudio preliminar, selección y notas de Gregorio Weinberg. Buenos Aires: Centro Editor de América Latina, 1984.

AZEVEDO, Aluísio. O mulato. São Paulo: Martin Claret, 2004.

BURKE, Peter. Os usos da alfabetização no início da Itália Moderna. In: BURKE, Peter; PORTE, Roy (orgs.). História social da linguagem. São Paulo: Unesp, 1997, p. 15-41.

CONDORCET, Jean Antoine Nicolas de Caritat, Marquis de. Cinco memórias sobre a instrução pública. São Paulo: Unesp, 2008.

CONDORCET, Jean Antoine Nicolas de Caritat, Marquis de. Escritos sobre a instrução pública. Campinas: Autores Associados, 2010.

CUNHA, Euclides. Os sertões [1902]. In: SANTIAGO, Silviano. Intérpretes do Brasil. Volume I. 2. ed. Rio de Janeiro: Nova Aguilar, 2002, p. 193-606.

CUNHA, Euclides. Diário de uma expedição. São Paulo: Companhia das Letras, 2000.

CURY, Carlos Roberto Jamil. Direito à educação: direito à igualdade, direito à diferença. Cadernos de Pesquisa, n. 116, 2007, p. 245-262.

DAIBERT JUNIOR, Robert. Canudos como vendeia brasileira? Ou os embates da consciência revolucionária republicana nas leituras euclidianas de Hugo e dos sertões baianos. Revista de História, v. 10, n. 1, 2004, p. 65-77.

ELIAS, Norbert; SCOTSON, John L. Os estabelecidos e os outsiders. sociologia das relações de poder a partir de uma pequena comunidade. Rio de Janeiro: José Olympio, 2000.

FERRARO, Alceu Ravanello. Neoliberalismo e políticas sociais: a naturalização da exclusão. Estudos Teológicos, São Leopoldo, v. 45, n. 1, 2005, p. 99-117.

GROULT, Benoîte. Le feminisme au masculin. Paris: Grasset, 2010.

HOSSEINI, Khaled. O caçador de pipas. Rio de Janeiro: Nova Fronteira, 2005.

HUGO, Victor. L'Homme qui Rit [1869]. Introduction de Pierre Albouy. Édition établie e annotée par Roger Borderie. Texte Integral. Paris: Gallimard, 2002a.

HUGO, Victor. Os miseráveis [1862]. Tradução: Frederico Ozanan Pessoa de Barros. Apresentação: Renato Janine Ribeiro. São Paulo: Cosac \& Naify, 2002b. 
HUGO, Victor. Quatrevingt-Treize [1874]. Introduction e notes par Bernard Leuilliot. Paris: Librairie Générale Fraçaise, 2001.

HUGO, Victor. Les miserables [1862]. Paris: Librairie Générale Francaise, 2000a.

HUGO, Victor. Le dernier jour d'un condamné [1829]. Édition de Roger Borderie. Paris: Gallimard, 2000b.

LAVALLE, Adrián Gurza. Cidadania, igualdade e diferença. Lua Nova, n. 59, 2003, p. 7594.

LEE, Harper. O sol é para todos. Rio de Janeiro: José Olímpio, 2007.

LEULLIOT, Bernard. Introduction. In: HUGO, Victor. Quatrevingt-treize. Paris: Librairie Générale Fraçaise, 2001, p. 7-43.

LUKÁCS, György. O romance histórico. São Paulo: Boitempo, 2011.

MARINHO, Maria de Fátima. Victor Hugo e o romance histórico. Disponível em <http://ler.letras.up.pt/uploads/ficheiros/4387.pdf>. Acesso em 28 ago. 2011.

MARX, Karl. A ideologia alemã. São Paulo: Boitempo, 2007.

MARX, Karl. O 18 brumário e Cartas a Kugelmann. Rio de Janeiro: Paz e Terra, 1997.

PERROT, Michelle. As mulheres ou os silêncios da história. Bauru: Edusc, 2005.

PIERUCCI, Antônio Flávio. Do feminismo igualitarista ao feminismo diferencialista e depois. In: BRABO, Tânia Suely Antonelli Marcelino (org.). Gênero e educação: lutas do passado, conquistas do presente e perspectivas futuras. São Paulo: Ícone, 2007, p. 3044.

PIERUCCI, Antônio Flávio. Ciladas da diferença. São Paulo: USP/34, 2008.

RIBEIRO, Rosália Cristina Costa. O espaço revolucionário em Quatrevingt-treize de Victor Hugo. Revista Intertexto, Uberaba, v. 1, n. 2, 2008, p. 130-146. Disponível em <http://revistaintertexto.letras.uftm.edu.br>. Acesso em: 20 jul. 2011.

SCOTT, Joan W. O enigma da igualdade. Estudos Feministas, Florianópolis, v. 13, n. 1, 2005, p. 11-30.

SCOTT, Joan W. A cidadã paradoxal: as feministas francesas e os direitos do homem. Florianópolis: Mulheres, 2002.

SOWERWINE, Charles, GRIMSHAW, Patricia. Equality and difference in the twentiethcentury west: North America, Western Europe, Australia, and New Zealand. In: MEADE, Teresa A., WIESNER-HANKS, Merry E (ed.). A companion to gender history. Oxford, UK: Blackwell, 2006, p. 586-610.

ALCEU RAVANELLO FERRARO é doutor em Ciências Sociais pela Pontifícia Universidade Gregoriana, Roma, professor titular aposentado da Universidade Federal do Rio Grande do Sul e docente convidado do Programa de PósGraduação em Educação da mesma universidade.

Endereço: Rua Dona Laura, 924/201 - 90430-090 - Porto Alegre - RS - Brasil.

E-mail: aferraro@ufrgs.br.

Recebido em 19 de outubro de 2015.

Aceito em 30 de novembro de 2015. 